\title{
THE FINANCING OF THE SOUTH AFRICAN WAR
}

When on October 20, 1899, the Chancellor of the Exchequer presented to the British Parliament his first estimate for the South African War, the government proposed to finish the war in four months with an army of about 50,000 men, and at a cost of $£ 10,000,-$ $\infty$, which was thought to be a very liberal estimate. The war was finally terminated in June, Ig02, after employing an army of 250,ooo men and involving an expenditure of over $\$ 200,000,000$. It has been in some respects one of England's greatest wars. Many problems are presented in the financing of a modern war of such magnitude, and it is the object of this paper to give a brief account of the financial operations that have taken place and to discuss certain features which may be of interest to the student of public finance.

The South African War began in October, of the year I899. On the seventeenth of that month a special session of Parliament was called and the first demand for the cost of the war was presented on the twentieth. Ten million pounds were asked for, of which $£ 2,000$,000 were for the cost of reinforcements sent prior to the outbreak of hostilities and $£ 8,000$, 000 were to cover all expenses up to March $3 \mathbf{r}$, I900, when it was assumed that the war would certainly be over. The inability of the government to forecast with any degree of accuracy the probable duration or cost of the war has been the rule from first to last. Estimates have been regularly insufficient, necessitating large supplementary estimates in rapid succession.

To meet this grant of $£ 10,000,000$ power was given to borrow $£ 8, \infty 00,000$ by treasury bills, the balance being made up from the surplus of revenue over ordinary expenditure which was estimated at $f_{3}, 000$,ooo for the year.

This grant was soon used up and on February I2, Igoo, a second estimate of $t_{13}, 000,000$ was presented, making a total of f23,000,000 voted for the war in the fiscal year 1899-1900.

Early in the year 1900 it became evident that the war was going to be long and costly and that some definite provision would have to be made to meet the necessary expenditure. Consequently, $[534]$ 
Sir Michael Hicks-Beach took the very unusual step of presenting his Budget early in March, more than a month before the regular time. It is unnecessary to go into the estimates of receipts and expenditure in this Budget since they had to be materially revised in a statement issued at the close of the fiscal year. Suffice it to say that the government found itself with an estimated deficit for

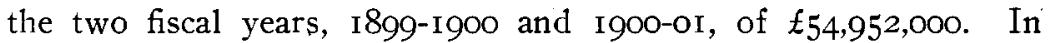
introducing his plan for providing this amount the Chancellor of the Exchequer dismissed at once the idea of depending on borrowing for the whole sum. He proposed to call upon the taxpayers for an inmediate and specific sacrifice. Believing, however, that the expenditure was only a temporary necessity, he did not think it wise to make any permanent fiscal changes but would obtain what was needed by increasing existing taxes. The following changes were made:

I. An increase in the rate of the income tax from $8 d$. to is., estimated to yield $£ 6,500,000$. This estimate was later increased to $£ 7,000,000$ and was even then too low.

2. An increase of $\mathrm{I} s$. per barrel in the beer tax, estimated to yield $E_{1}, 752,000$.

3. An increase of $6 d$. per gallon in the tax on spirits, estimated to yield $f$ I, o 5 , Ooo.

4. An increase of $4 d$. per pound in the tobacco tax, with an additional $6 d$. per pound on foreign cigars, estimated to yield EI, IOO,OOO.

5. An increase of $2 d$. per pound in the tea duty, estimated to

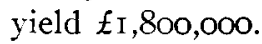

In all, these additional taxes were expected to yield $£_{12,167,000}$. A saving of $f_{4}, 640,000$ was made by suspending the sinking fund devoted to the payment of terminable annuities held by various government departments. To meet the balance of the deficit and leave a margin for contingencies the government was given power to borrow $£_{43}, 000,000$. Of this sum, $£ 8,000,000$ were obtained by reissuing treasury bills authorized in October, $1899, £_{5}, 000,000$ by new treasury bills and $£_{30,000,000}$ by an issue of war loan stock.

A revised financial statement was issued on April 6, from which we take the figures of revenue and expenditure for I899-I900 and the final estimates for I900-OI. The statement for $1899-1900$ is summarized as follows: 
Revenue $\ldots \ldots \ldots \ldots \ldots \ldots \ldots \ldots \ldots \ldots \ldots \ldots \ldots \ldots \ldots \ldots, 840,000$

Expenditure:

Ordinary $\ldots \ldots \ldots \ldots \ldots \ldots \ldots \ldots \ldots \ldots \ldots \ldots, 506,000$

War Charges.......... $23,000,000$

Interest on War Debt. 217,000

Total Cost of War........ 23,21, 7,000

Deficit

$\mathscr{L}_{13}, 88_{3,000}$

The estimates for I900-OI are as follows:

\section{Revenue:}

Customs ................ $\mathscr{L}_{23,620,000}$

Excise ................ 33,550,000

Estate Duty............... 13,000,000

Stamps.................. 8,550,000

Land and House Tax......... $2,45^{\circ, 000}$

Income $\operatorname{Tax} \ldots \ldots \ldots \ldots \ldots \ldots \ldots, 25,800,000$

Total Tax Revenue ........... $\mathscr{E}_{\mathrm{s} 06,970,000}$

Total Non-tax Revenue ....... 20,550,000

Total Revenue.....................

Expenditure:

Ordinary ................. 6 × $6,035,000$

War Charges........... $37,797,000$

Interest on War Debt.. 869,000

Total Cost of War........ 38,666,000

Total Expenditure .............. 154,701,000

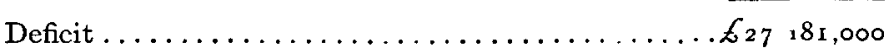

Deduct Sinking Fund suspended .......... $4,640,000$

$$
622,54 \div, 000
$$

Deficit for $1899-1900 \ldots \ldots \ldots \ldots \ldots \ldots \ldots \ldots, 882,000$

Final Deficit ...................... $\overline{£_{36,423,000}}$

To cover this deficit power had already been given to borrow

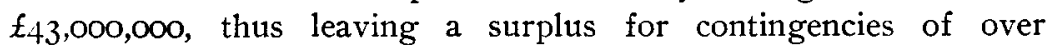
$£ 6,000,000$.

In less than five months the Chancellor of the Exchequer was compelled to ask Parliament for more money. Accordingly, on July, 
27, a supplementary estimate of $t_{1} 1,500,000$ was presented, of which $£ 7,440,000$ were for the South African War. To cover this and certain other supplementary grants, $£_{\mathrm{I} 3,000,000}$ were borrowed by an issue of Exchequer bonds. The second supplementary estimate of the year was presented on December II, and included $f_{1} 3,500$,ooo for war charges, $E_{\mathrm{I}}, 000,000$ for the "new Transvaal police," and $£ \mathrm{I}, \mathrm{O}, \mathrm{O}, \mathrm{OO}$ for repair of railways, etc., damaged in consequence of the war. After some quibbling over the sums properly chargeable to the war account, it was finally decided to include the whole $f_{1} 5,500,000$ under war expenditure. To meet this additional charge, another $E_{I} \mathrm{I}, 000,000$ of Exchequer bonds had to be issued in March, I90I. A third supplementary estimate was issued on February 28, I90I, amounting to $£ 3,000,000$ and making the total granted during the year for the war in South Africa $163,737,000$.

The summarized statement of receipts and expenditure for the year I900-OI is as follows:

Financial Statement, I900-OI

Revenue:

Customs................ $£_{26,262,000}$

Excise ................. 33,100000

Estate Duty................ $12,980,000$

Stamps ................. $\quad 7,825,000$

Land and House Tax......... $2,475,000$

Income $\operatorname{Tax} \ldots \ldots \ldots \ldots \ldots \ldots .26,920,000$

Total Tax Revenue .......... $\overline{t_{109,562,000}}$

Total Non-Tax Revenue ........ 20,823,000

Total Revenue................ \& $\&_{130,3} 8_{5: 000}$

Expenditure:

Ordinary........................ $\mathscr{L}_{\mathrm{II} 4,972,000}$

War in China.............. $3,500,000$

South African War....663,737,000

Interest on War Debt . I, 1,83,000

Total S. A. War .......... $65,120.000$

Total Expenditure ................ I $83,592,000$

Deficit covered by borrowing................ $\ell_{53,207,000}$

The Budget for I9OI-O2 was presented on April I8, I9OI, and contained an estimated deficit of $f 55,347,000$ for the year. Sir Michael Hicks-Beach introduced his proposals for meeting this deficit by calling attention to the alarming growth of ordinary 
expenditure and to the fact that practically all the additional taxation imposed for war expenditure a year ago would be required for ordinary expenditure during the coming year. Moreover, he admitted that the practical limit of productive taxation of beer, spirits, tea, and tobacco had been reached by his increased taxation of the past year, as was shown by the fact that, allowing for rushed clearances of dutiable goods just before the introduction of the Budget, practically all the sources of revenue had fallen short of his estimates. In view of these considerations he thought the time had come to put the financial system of the country on a broader basis. That he succeeded in doing this bevond a very limited extent will hardly be admitted. The following new or increased taxation was imposed:

I. An increase of $2 d$. in the income tax, bringing it up to Is. $2 d$. in the pound and estimated to yield $\mathfrak{f}_{3}, 800$, ooo during the year.

2. An import duty on sugar varying from $4 s$. $2 d$. per hundredweight for refined sugar, down to $2 s$. per hundredweight for the lowest grade of raw sugar. The yield was estimated at $£_{5}$, IOO,o0o.

3. An export duty on coal of $\mathrm{I} s$. per ton estimated to yield $£ 2,100,000$. These taxes will be discussed in more detail later on. Certain exemptions made in the coal duty before its final passage reduced its estimated yield by $£ 800,000$.

The sinking fund was again suspended, amounting to $t_{4}, 640,000$.

The estimates for I901-02, showing what sources of revenue were increased, may now be summarized as follows:

Estimates for $\mathrm{I} 90 \mathrm{O}-\mathrm{O} 2$

\begin{tabular}{|c|c|c|c|}
\hline REVENUE. & Existing Basis. & New Basis. & Increase. \\
\hline $\begin{array}{l}\text { Customs } \ldots \ldots \ldots \ldots \\
\text { Excise } \ldots \ldots \ldots \ldots \\
\text { Estate Duty } \ldots \ldots \ldots \ldots \\
\text { Stamps } \ldots \ldots \ldots \ldots \\
\text { Land and House Tax } \ldots \ldots \\
\text { Income Tax } \ldots \ldots \ldots \ldots\end{array}$ & $\begin{array}{r}L_{23}, 600,000 \\
33,100,000 \\
14,000,000 \\
8,000,000 \\
2,500,000 \\
30,000,000\end{array}$ & $\begin{array}{r}f_{30}, 800,000 \\
33,100,000 \\
14,000,000 \\
8,000,000 \\
2,500,000 \\
33,800,000\end{array}$ & $E_{7,200,000}$ \\
\hline $\begin{array}{l}\text { Total Tax Revenue........ } \\
\text { Total Non-Tax Revenue... }\end{array}$ & $\begin{array}{r}\operatorname{LrII}_{2}, 200,000 \\
2 \mathrm{I}, 055,000\end{array}$ & $\begin{array}{r}L_{I 22,200,000} \\
21,055,000\end{array}$ & $\delta \operatorname{LI}, 000,000$ \\
\hline Total Revenue & $\mathscr{L}_{\mathrm{I}_{32,255,000}}$ & $\delta_{143,255,000}$ & $\delta_{\text {II }, 000,000}$ \\
\hline
\end{tabular}


Expenditure:

Ordinary.

$E_{127,372,000}$

War in China.

$2,160,000$

South African War

$\measuredangle_{56,070,000}$

Interest on War Debt

$3,125,000$

Total South African War.

$59,195,000$

Total Expenditure

E188,727,000

Deficit.

$45,472,000$

Deduct Sinking Fund suspended

$4,640,000$

Final Deficit

$\widetilde{\delta_{40,832,000}}$

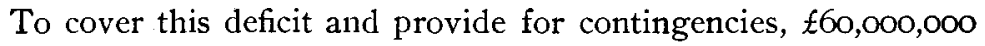
were borrowed by an issue of consols.

The next vote for the cost of the war was the grant of $£_{100,000}$ to Lord Roberts, in recognition of his services in South Africa, passed on July 3I. This was followed, on August 6, by a civil service estimate containing $£ 6,500$, 000 for a grant in aid for the Transvaal and Orange. River Colony which was classed in the official accounts as expenditure to be charged to the cost of the war. Finally on January 31, I902, a supplementary army estimate of $t_{5}, 000,000$, to defray additional expenses due to the war in South Africa, was voted. In all, therefore, $£ 67,670,000$ were voted during the year for the war.

The actual receipts and expenditure of the year I90I-O2 may now be summarized as follows:

\section{Financial Statement, I90I-02}

Revenue:

Customs . . . . . . . . . . . . $\ell_{30,993,000}$

Excise............................... $3^{1,600,000}$

Estate Duty ............... I4,200,000

Stamps ................. 7,800,000

Land and House Tax......... $\quad 2,500,000$

Income $\operatorname{Tax} \ldots \ldots \ldots \ldots \ldots \ldots \ldots \quad 34,800,000$

Total Tax Revenue ..............

Total Non-Tax Revenue........ 2I, I05,000

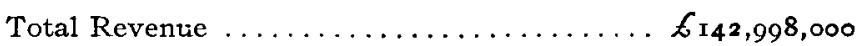




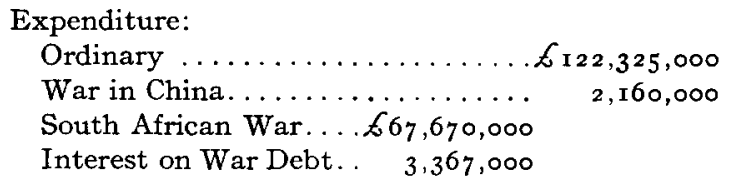

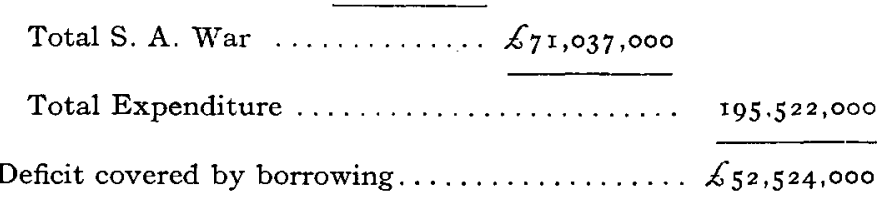

In his Budget for 1902-03, which was. presented on April I4, I902, Sir Michael Hicks-Beach was again confronted with a large deficit. The army estimates issued some time previously had put the war charge for South Africa at $\pm_{39}, 650,000$. There was also a civil service estimate of $£_{1}, 800,000$ for South Africa. These estimates, however, were based on the assumption that the war would be over in eight or nine months, and they contained no provisions for transportation home, gratuities to the troops, and other charges incidental to the close of the war. Accordingly, in his Budget speech, the Chancellor of the Exchequer said that while present indications seemed to point to an early conclusion of the war, he did not feel justified in basing his estimates on this hope. He therefore added $f_{17}, 000,000$ to the army estimates to cover the expenditure for the remainder of the year, together with $£ 750,000$ for the South African constabulary and $£ 750$,000 for interest on the new debt to be created. This brought up the total for the war to $\pm 63,600,000$, involving an estimated deficit on the existing basis of taxation of $\mathfrak{t}_{45}, 324,000$.

To cover this deficit in part the following proposals were made:

I. To increase the income tax by $\mathrm{I} d$., bringing it up to $15 d$. This was estimated to yield $£ 2,000,000$.

2. To raise the tax on bills at sight, including bank checks

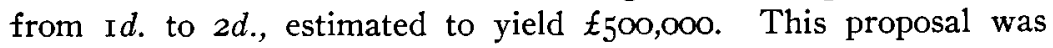
withdrawn before the final passage of the finance bill.

3. To impose a registration duty on imported corn of $3 d$. per hundredweight and on flour and meal of $5 d$. per hundredweight, estimated to yield $£ 2,650,000$.

4. To suspend the sinking fund as before, amounting to about $\mathfrak{t}_{4}, 640,000$. 
These proposals amounted together to $£ 9,790,000$ and reduced the deficit to $\mathfrak{E 3 5} \cdot 534,000$. The estimates, on existing and proposed taxes, are summarized as follows :

\section{Estimatcs for $1902-03$}

\begin{tabular}{|c|c|c|c|}
\hline Revenue. & Existing Basis. & Proposed Basis. & Increase. \\
\hline Customs. & $\mathscr{E}_{32,800,000}$ & $E_{35,450,000}$ & $E_{2}, 650,000$ \\
\hline Excise ..... & $3^{2}, 700,000$ & $3^{2,700,000}$ & \\
\hline Estate Duty & $13,200,000$ & I3,200,000 & \\
\hline Stamps... . . . . . . & $8,200,000$ & $8,700,000$ & $500,000^{1}$ \\
\hline Land and House Tax & $2,500,000$ & $2,500,000$ & \\
\hline Income $\operatorname{Tax} \ldots \ldots$ & $36,600,000$ & $3^{8,600,000}$ & $2,000,000$ \\
\hline Total Tax Revenue .... & $\mathscr{L}_{\mathrm{I} 26,000,000}$ & $\mathscr{E}_{131,{ }_{1} 0,000}$ & $t_{5}, 150,000$ \\
\hline Total Non-Tax Revenue . & $2 \mathrm{I}, 785,000$ & $21,785,000$ & \\
\hline Total Revenue & $6_{147,785,000}$ & $\delta_{I_{5}, 935,000}$ & $t_{5}, 1_{50,000 .}$ \\
\hline
\end{tabular}

Expenditure:

Ordinary ...........................

War in China....................... 350,000

South African War.............. $59,200,000$

Interest on War Debt.......... 4,400,000

Total South African War................ $\mathbf{6}_{3}, 600,000$

'lotal Expenditure .................. $6 \mathscr{1}_{\mathrm{r} 93,109,000}$

Deficit ........................ $40,174,000$

Deduct Sinking Fund suspended........... $\quad 4_{4,640,000}$

Final Deficit.............................

To meet this deficit in part an issue of $£ 32,000,000$ consols was made, the remainder being covered by the Exchequer balances.

For once the government estimates proved to be in excess of the needs, and the close of the war on May 3I, I902, necessitated a revision in the estimates for the year. The charge for the South African War was reduced by $£_{17}, 000,000$, leaving $£_{42,200,000}$ to meet the expense of operations during April and May and the

1 Withdrawn before the passage of the finance bill 
various terminal charges, the latter being estimated at $£ 28$,ooo,ooo. The sinking fund, which had been suspended during the war, was renewed for the year $1902-03$. These changes made the estimates for $1902-03$ foot up as follows:

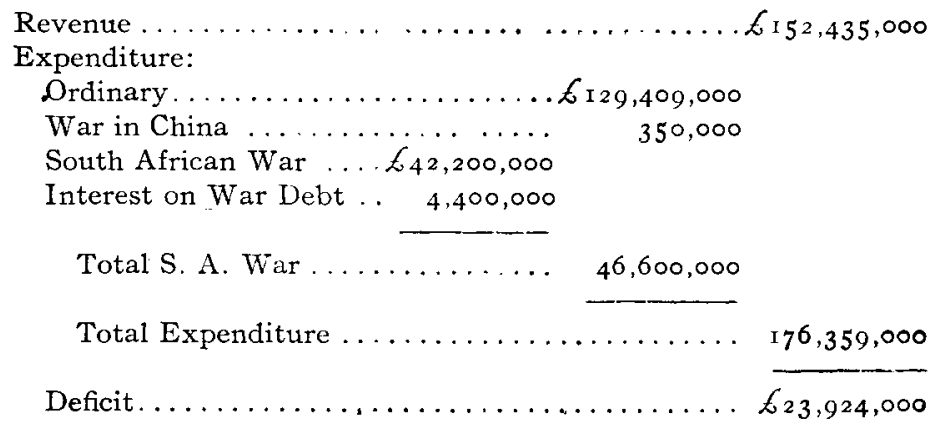

This deficit was more than covered by the proceeds of the consols loan of April.

To complete the estimate of the war charges for 1902-03, we must add the grant of $\mathfrak{f 5}_{5}^{\circ}$,ooo voted to Lord Kitchener on June 5 , making the total estimated cost of the South African War during I902-03 $£_{46} 6,650,000$.

\section{The War Taxes}

As has been shown, no radical changes in the revenue system were made in the year I900-OI. The legislation consisted merely in increasing the rates of existing taxes. The Chancellor was criticized for lack of financial resource in not accepting the opportunity then given him to rearrange the revenue system and to make certain needed improvements, notably in the beer license tax, the stamp duties, and in the grants in aid to local bodies. That lack of foresight was shown, seems to have been proved by the year's revenue. In the Budget, presented at the beginning of the next year, it was admitted that the limit of profitable taxation of beer, spirits, tea and tobacco had probably been reached. Moreover, the yield of the stamp duty had been discouraging, having fallen $£ 725,000$ below the estimate, on account of "prolongation of the war and the practical absence of business on the Stock Exchange." Practically the 
only sources of revenue that had not fallen short of the estimates were the customs and the income tax, the exception in the case of the former being accounted for by the forestallment of customs and excise payments amounting to nearly three and a quarter millions of pounds which properly belonged to the revenue of the next year. The Economist also suggests that the income tax had been collected with unusual severity during March, so that there would doubtless be less in the way of arrears to be carried forward to the revenue of I9OI-02. Evidently, then, the revenue system had not been improved by the legislation of the year. To quote from the Economist, of April 6, I901: "When allowance is made for these exceptional causes of increase, it is pretty clear that the income proper of the past year, instead of exceeding the estimates, as a mere comparison of the aggregate figures would show, really fell short of it, and that, owing to the pressure of augmented taxation and of slackening trade, the spring has, temporarily at all events, been taken out of the revenue."

Another cause of criticism of the taxation of the year was the heavy burden placed upon the income taxpayers, that tax, as has already been shown, being called on for more than half of the increased taxation.

In the Budget for $190 \mathrm{I}-02$, the increased rates of the year before on beer, spirits, tobacco and tea were retained, the income tax rate was raised $2 d$., and two new taxes were introduced, viz, an import duty on sugar and an export duty on coal. There used to be a tax on sugar but it was given up "some twenty-seven years ago because it was troublesome to collect and hampering to business." 2 No tax on coal of the kind.proposed had been levied for fifty-five years. The sugar tax involved a good many technical complications, but these seem to have been met very well. The tax met with little opposition and has been a success financially. The yield was $f 6,410,000$ during $190 \mathrm{I}-02$, which exceeded the estimate by $t_{1}, 310, \infty 00$, the reason for this large excess being, as explained to Parliament by Sir Michael Hicks-Beach, "that there were large forestallments on sugar in December, January, and February, in anticipation, perhaps, of an increased duty."

On the other hand, the coal duty, as proposed, met with very serious opposition. Discussion and debate were carried on in Par-

2 Economist, April 20, rgor. 
liament and by the press for over two months, strikes were threatened by the coal workers, and the bill was not passed till the Chancellor of the Exchequer agreed to exempt from duty all coal exported up to December $3 \mathrm{I}$, under contracts entered into before the date of the Budget, and also to give a rebate of the duty on the cheapest coal (that proved to be worth less than $6 s$. per ton, free on board). These concessions, which reduced the estimated rield of the duty by $£ 800,000$ seemed to satisfy the trade and practically put an end to criticism. This duty has also been a financial success, and it has not produced the evil effects prophesied of it. The yield

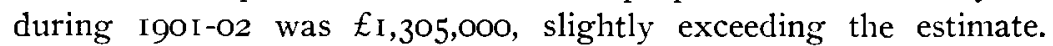
So far from reducing exports of coal or seriously affecting the English coal trade, the exports during the year, amounting to $44,064,000$ tons, exceeded those of any previous year except the record year of IgO0-OI.

The other parts of the customs and excise systems remained weak during the year, most of the duties showing a decrease from the estimates and from the receipts of the year before. The yield of the income tax was again very large, being $£_{34}, 800$,ooo, a full million pounds over the estimate.

No financial legislation during the war has aroused such widespread interest and discussion as the corn duty proposed in the Budget for 1902-03. It will be impossible within the limits of this paper to more than indicate the main lines of that discussion. The tax is attacked mainly on the following grounds: (I) It taxes the minimum of subsistence of the people; (2) by raising the price of home-grown, as well as imported grain, it will take more from the people than the treasury will receive, the balance going to the benefit of a favored class; (3) it opens the way for a possible future attack on England's free trade policy. Moreover, the duty may be used to give preferential tariffs in favor of the colonies and so aid in bringing about some form of Imperial customs union, and it is claimed on good authority that this is the government's real motive in imposing the tax.

The friends of the tax affirm that it is too small to place any appreciable burden on the poor or to lead to the cultivation of new tracts of land in England. All are eager to deny any protective tendencies in the duty or any ulterior motive behind it. No strong or united opposition developed against the tax either in the country 
or in Parliament and it was passed with a few unimportant modifications.

The income tax was again raised in 1902 by $\mathrm{I} d$., and in this connection there was a renewal of the criticism which met the increase of this tax on each of the two preceding years. Those who criticize this increase do not deny the fact that the income tax is a proper source for extra revenue in time of war or other emergency; in fact, it is on this very ground that they base their complaint. During the Crimean War the rate rose to Is. $4 d$., I $d$. higher than the present rate, but that was a temporary war rate and was speedily reduced when peace was restored. This use of the income tax to swell the revenue during times of temporary emergency is regarded as one of its main functions. But while the South African War has been going on, the ordinary expenditure of the government has been increasing at such a rate that the three successive additions to the income tax cannot be regarded as temporary measures but have become necessary to cover ordinary expenditure. This is shown by the following table which gives the ordinary expenditure, war charges, and revenue for a number of years. Interest on war debt is included in ordinary expenditure since it is not stopped by the close of the war. War charges include the war in China.

The Growth of Ordinary Expenditure

\begin{tabular}{|c|c|c|c|}
\hline & $\begin{array}{c}\text { Ordinary } \\
\text { Expenditure. }\end{array}$ & War Charges. & Revenue. \\
\hline I879-80 & $\not 82,185,000$ & & $E_{79,344,000}$ \\
\hline I $889-90$ & $86,083,000$ & $\cdots$ & $89,304,000$ \\
\hline I $896-97$ & $101,477,000$ & & $103,950,000$ \\
\hline I $897-98$ & $102,936,000$ & & $106,6 I_{4}, 000$ \\
\hline I898-99 $\ldots \ldots \ldots \ldots \ldots$ & $108,150,000$ & & $108,366,000$ \\
\hline $1899-1900 \ldots \ldots \ldots \ldots \ldots$ & I I0,723,000 & $E_{23}, 000,000$ & I I $9,840,000$ \\
\hline $1900-01 \ldots \ldots \ldots \ldots$ & I I6, 355,000 & $67,237,000$ & $130,385,000$ \\
\hline $1901-02$. & I $25,692,000$ & $69,830,000$ & I $42,998,000$ \\
\hline $1902-03^{3}$ & $133.809,000$ & $42,600,000$ & I $52,435,000$ \\
\hline
\end{tabular}

Bstimated. 
The same facts are shown in the accompanying chart.

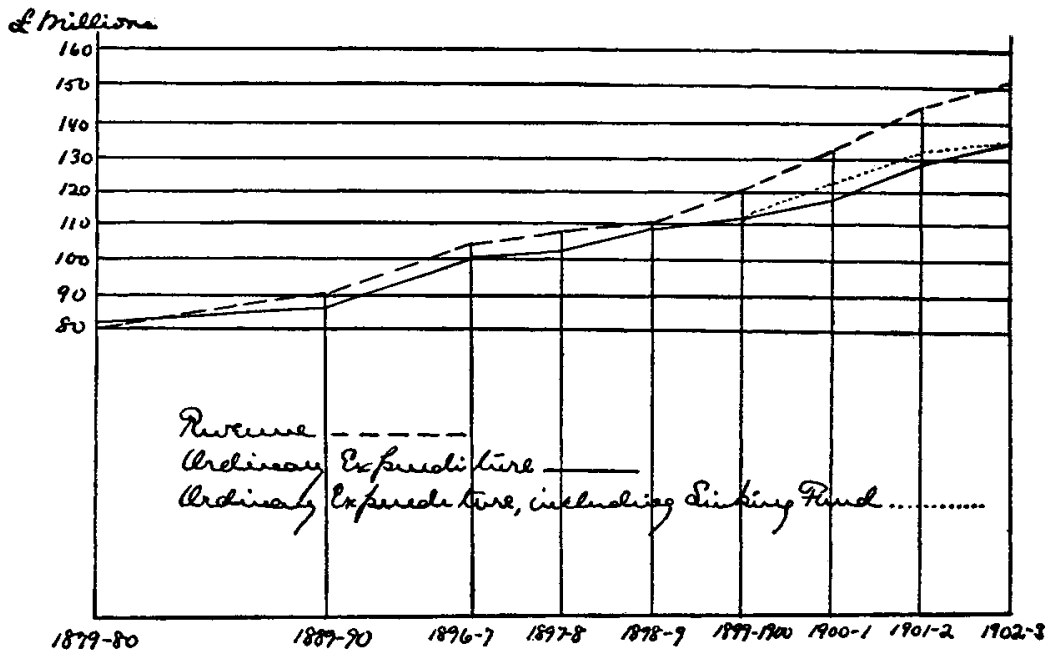

The above tables show the remarkable growth of ordinary expenditure and also bring out the fact that since the beginning of the war the ordinary expenditure of each year is not far behind the revenue of the preceding year. Even as it is, the table puts too favorable a light on the matter, for the ordinary expenditure has been kept down during the war by suspending the sinking fund, to the amount of over four and a half million pounds. This is really a part of the ordinary expenditure and it has been resumed since the war closed. Adding this sum (see chart) makes the ordinary expenditure of I900-OI exceed the revenue of the year before, while the ordinary expenditure of I9OI-O2 almost exactly balances the revenue of the previous year. If the growth of ordinary expenditure goes on at the rate of the last three years (increasing about $£ 8,000,000$ annually), it will take only about two years to come to the point where all the existing sources of revenue will be required to meet ordinary expenditure. Thus the additional taxation laid each year ostensibly for war charges is being practically required to balance the ordinary expenditure of the year following, and hence the justice of the complaint against the heavy increase of the income tax.

The following detailed statement of the articles taxed and the 
revenue obtained by the war taxes is taken from a Parliamentary paper which appeared on April 30, 1902 :

Reccule from New Tates Imposed for the War.

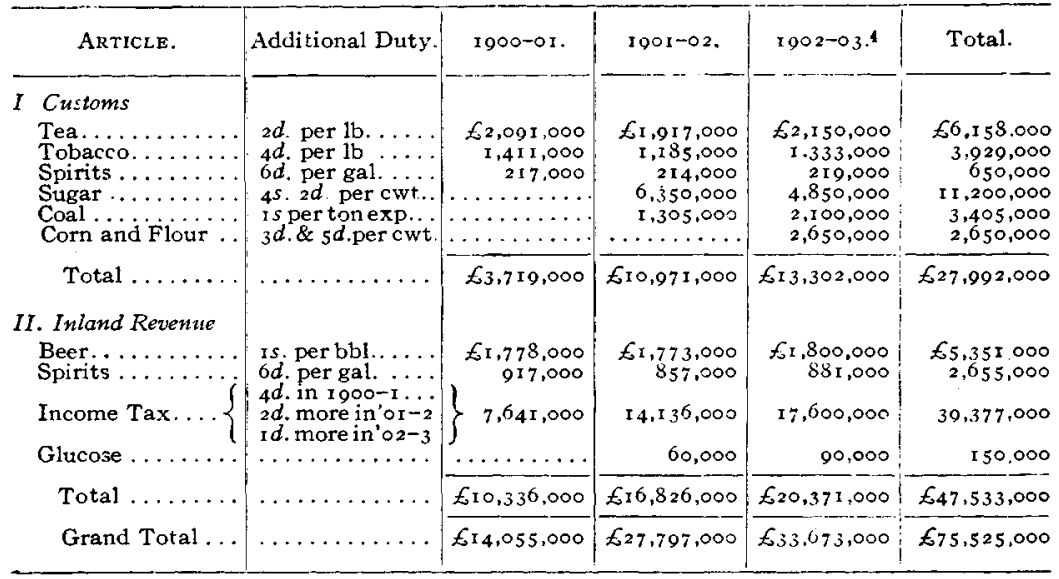

The Government Borrowing.

As already referred to incidentally, the borrowing for the South African War expenses has taken four forms, viz, treasury bills, Exchequer bonds, consols and the "National War Loan." The first borrowing took place in November, I899, when $£_{3}, 000,000$ of treasury bills were issued. Before the close of that fiscal year $£_{5}, 000$,000 more were issued and another $£_{5}, 000$, o0o were issued during I900-or, making a total of $\mathrm{Er}_{\mathrm{r}} 3,000,000$ borrowed by this form of obligation. On March 3I, I899, that is before any borrowing had been done on account of the war, there were outstanding $f 8, \mathrm{I} 33,000$ of treasury bills. The war borrowing has brought this sum up to a little over $£_{21}, 000,000$. These bills are all issued for periods of three, six, nine, or twelve months and as they have generally been replaced by fresh issues as fast as they fell due the amount outstanding has been kept pretty nearly constant. On March I, 1902, there were exactly $f 2 \mathrm{I}, \mathrm{I} 33,000$ outstanding. This continued renewal has necessitated the placing of from one to three millions of treasury bills on the market nearly every month. The number of applicants and the

- Estimated. 
average discount rates have fluctuated considerably, depending mainly on the condition of the money market and the prevailing discount rates.

The first loan other than by treasury bills was made in March, I900. It took the form of a "National War Loan" of stock bearing $23 / 4$ per cent interest and redeemable at par in ten years, that is, on April 5, rgro. The issue price was fixed by the government at $981 / 2$. The success of the loan was enormous, the total amount applied for being $£_{335}$,000,000, or more than ten times the amount to be allotted, and the stock was immediately quoted at a premium on the Exchange. There was some criticism of the form of the loan and complaint that the government had not obtained better terms. At the time the issue was announced, consols were quoted at Ior, and consequently $98 \mathrm{r} / 2$ seemed a low price to be set on the new stock, especially as the interest rate on consols falls to $2 \frac{1}{2}$ per cent in I903, while the new stock will pay $23 / 4$ per cent till redeemed in I9I0. Undoubtedly the success of the loan shows that the government might have obtained better terms, but this could not have been foreseen, and there was great risk involved in putting the price too high. The aim of the government was to issue a popular loan on such terms that there would be a great demand to take it on the part of the British public, in order to show to the world that the government was well able to finance the war and had the confidence of the nation behind it. England, at this time, was being watched by Europe in no friendly spirit, and the loss of prestige resulting from a feeble response to the loan would have been serious. The reason that the loan took the form that it did, instead of being floated by an issue of consols, was mainly that the Chancellor of the Exchequer wanted to be able to pay it off at par at an early period, as he anticipated that consols would rise considerably above par again at the close of the war. The general opinion as to the wisdom and success of the loan was very favorable.

By the middle of the year it again became necessary to borrow money, and before the close of the fiscal year, Igoo-or, three loans had been issued, all taking the form of Exchequer bonds, and amounting in all to $£ 24,000,000$. In August, 1900, $£_{10,000,000}$ Exchequer bonds were issued, bearing interest at 3 per cent, repayable at par in three years (August 7,1903 ). The issue price was fixed at 08 . The attitude of the government with respect to this 
loan is in marked contrast with its position in the case of the war loan issued in March. Then an appeal was made to the patriotism of the people in order to show to the world Great Britain's financial strength, and certainly no fault could have been found with the response. Now, however, the government does not dare depend

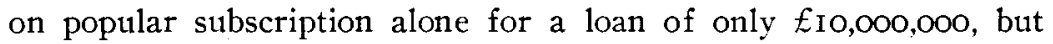
before advertișing for applications from the public has taken the precautionary measure of arranging with certain Anglo-American firms to place half the loan in the United States. In answer to a question in Parliament, the Chancellor of the Exchequer explained this action thus: "Before settling what the issue should be, I had endeavored to ascertain by the usual confidential inquiries whether the terms $I$ felt justified in giving would be likely to attract subscribers here. I received such very moderate encouragement that I accepted an offer made to me by leading Anglo-American houses in London to place half the issue in the United States on the terms I had decided to offer it here." The lists of applications were closed on the same day on which they were opened, as soon as the necessary amount had been applied for. The Chancellor of the Exchequer met with considerable criticism for his lack of confidence and for other circumstances connected with the loan.

A second issue of Exchequer bonds was made in November, I900. The amount was $£_{3}, 000,000$ bearing interest at 3 per cent and redeemable in five years (December 7,1905 ). The price was not fixed in advance by the government, but the bonds were allotted to the highest bidder in the same way as an issue of treasury bills. The average price realized was $£_{9} 8$ 2s. Iod., being thus more favorable to the government than the price fixed for the issue in August. The applications amounted to $£ 6,263,500$. The third issue of Exchequer bonds took place in February, I901: $£_{1 \mathrm{I}}, 000,000$ were issued, bearing interest at 3 per cent and repayable at par in five years (December 7,1905 ), thus ranking exactly the same as the last issue. The amount applied for was $£ 25,390,700$ and the average price obtained was $£_{97} 5 s .4 d$., a considerable drop since the last issue, less than three months before.

Thus far the borrowing had all been by means of additions to the unfunded debt. But when in April, 190I, it became necessary to provide for an estimated deficit of over $£_{40,000,000}$ it was recognized that to obtain so large a sum by any form of temporary bor- 
rowing was not wise. Consequently, the $£ 600,000,000$ which were needed, were obtained by an issue of consols. The stock was to rank the same as the existing consols which bear interest at $23 / 4$ per cent till 1903 and then at $2 \mathrm{r} / 2$ per cent till 1923 , after which they may be redeemed as Parliament shall direct. Before advertising for subscriptions, half of the loan was allotted to banking houses as follows : $\mathfrak{E}_{\mathrm{II}, 000,000}$ to N. M. Rothschild \& Sons, $\mathfrak{E}_{\mathrm{IO}, 000,000}$ to J. S. Morgan \& Co., and $£_{9}, 000,000$ to the Bank of England. The remaining $£ 30,000,000$ were offered for public subscription at the price of $94 / 2$. Payments were to be made in monthly installments, the last payment being on December 5, I90I. As before there was some criticism of the private placing of half the loan, but on the whole, the Chancellor of the Exchequer is thought to have acted wisely in taking this precaution. The popular subscription was very successful, the $£_{30,000,000}$ being subscribed for six or seven times over.

No further borrowing was necessary till the beginning of the next fiscal year. On April 16, 1902, public subscriptions were invited for $\epsilon_{\mathrm{I}} 6,000,000$ of consols, being half of an issue of $£_{32,000 \text {,- }}$ $\infty 00$ authorized by Parliament. The other $£_{\mathrm{I}} 6,000,000$ were placed in advance with American and British banking houses. As before, the consols were to rank with the existing $23 / 4$ per cent stock, dropping to $2 \frac{1}{2}$ per cent in 1903 and redeemable at par in 1923 . Payment was to be made in monthly installments, the last installment being due on October 9, I902. The price fixed was $93 \% 2$. There was a tremendous rush to obtain the stock and the loan was largely oversubscribed. The stock was immediately quoted at a premium.

The war borrowing is summarized in the following table:

\section{Summary of Government War Loans}

\begin{tabular}{|c|c|c|c|c|c|}
\hline & $1890-1900$. & I $900-0 \mathrm{I}$ & IDOI-O2. & $1902-03$. & Total. \\
\hline $\begin{array}{l}\text { Treasury Bills...... } \\
\text { National War Loan } \\
\text { Exchequer Bonds... } \\
\text { Consols.............. }\end{array}$ & $\begin{array}{l}£ 8, \infty 00,000 \\
\cdots \cdots \cdots \cdots \cdots \\
\cdots \cdots \cdots \cdots \\
\cdots \cdots \cdots\end{array}$ & $\begin{array}{r}\ldots 5,000,000 \\
30,000,000 \\
24,000,000 \\
\ldots \ldots \ldots \cdots\end{array}$ & \begin{tabular}{l}
$\ldots \ldots \ldots \ldots \ldots$ \\
$\ldots \ldots \ldots \ldots \ldots$ \\
\hdashline $60,000,000$
\end{tabular} & 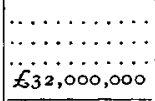 & $\begin{array}{r}E \mathrm{r} 3,000,000 \\
30,000,000 \\
24,000,000 \\
92,000,000 \\
\end{array}$ \\
\hline Total ........... & $£ 8,000,000$ & $€ 59,000,000$ & $£ 60,000,000$ & $£_{632,000,000}$ & $E_{\mathrm{I} 59,000,000}$ \\
\hline
\end{tabular}


The main details of the war loans, other than by menas of treasury bills, are given in the following table:

\section{Details of the War Loans (Exccpt Treasury Bills)}

\begin{tabular}{|c|c|c|c|c|c|c|}
\hline $\begin{array}{l}\text { Date of } \\
\text { Issue. }\end{array}$ & Form of Loan. & Am't Issued. & Price. & Net Proceeds. & Time. & Rate. \\
\hline $\begin{array}{l}\text { 1900. Mar. } \\
\text { 1900. Aug. } \\
\text { 1900. Nov. } \\
\text { I901. Feb. }\end{array}$ & $\begin{array}{l}\text { Nat'1 War Loan } \\
\text { Exchequer Bonds } \\
\text { Exchequer Bonds } \\
\text { Exchequer Bonds }\end{array}$ & $\begin{array}{r}£ 30,000,000 \\
10,000,000 \\
3,000,000 \\
11,000,000\end{array}$ & $\begin{array}{l}981 / 2 \ldots \ldots \\
98 \ldots \ldots \ldots \\
98 \text { 2s. rod. } \\
97 \text { 5s. } 4 \text { d. . }\end{array}$ & $\begin{array}{r}£ 29,519,000 \\
9,790,000 \\
2,944,000 \\
10,689,000\end{array}$ & $\begin{array}{r}\text { Io years } \\
3 \text { years } \\
5 \text { years } \\
5 \text { years }\end{array}$ & $\begin{array}{l}2 \% \% \\
3 \% \\
3 \% \\
3 \% \\
3 \% \%\end{array}$ \\
\hline I901. Apr. & Consols ....... & $60,000,000$ & $943 / 2 \ldots$ & $56,553,000$ & to 1923 & $\left\{\begin{array}{l}2 \\
\text { and } \\
212 \%\end{array}\right.$ \\
\hline I902. Apr. & Consols & $32,000,000$ & $931 / 2 \ldots$ & $29,920,000$ & to 1923 & $\left\{\begin{array}{l}2 \% / 2 \% \\
\text { and } \\
21 / 2 \%\end{array}\right.$ \\
\hline Total & & $E_{14} 6,000,000$ & & $£_{139,4}+5,000$ & & \\
\hline
\end{tabular}

As was to be expected the heavy borrowing of the British Government during the past three years has caused a considerable decline in consols and other government securities. It must not be concluded from this, however, that the credit of the government has been impaired. There is nowhere the slightest evidence that Englishmen have had their confidence in the national credit shaken. There has been plenty of feeling against the war, growing impatience at the inefficiency and mismanagement of the authorities, but nowhere any uncertainty as to the ultimate ability of the nation to conquer its enemies and pay its debts. We will attempt to point out briefly some of the main forces which have brought about the recent decline in consols. To show the movement during the past six years the following table is given:

\section{Prices of Consols at Selected Dates}

End of July, $1896 \ldots \ldots \ldots \ldots$ I $3 \frac{3}{8}$

End of July, I $898 \ldots \ldots \ldots$ II $\frac{1}{4}$

End of February, $1899 \ldots \ldots$. . III $\frac{1}{4}$

End of March, I $899 \ldots \ldots \ldots \ldots$. . I $10 \frac{5}{8}$

End of May, I $899 \ldots \ldots \ldots \ldots$. . . . 095

End of June, I $899 \ldots \ldots \ldots \ldots$. . . . $707 \frac{7}{8}$

End of July, I $899 \ldots \ldots \ldots \ldots$. . . I06 $\frac{5}{8}$

End of August, $1899 \ldots \ldots \ldots 105 \frac{5}{8}$

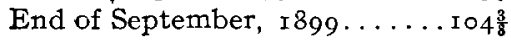

End of October, $1899 \ldots \ldots \ldots$ I04

End of November, I $899 \ldots \ldots$. . I0 $2 \frac{5}{8}$

End of July, r goo . . . . . . 93

End of January, r $901 \ldots . . . .9696 \frac{3}{4}$

End of July, I $901 \ldots \ldots \ldots . . .93$

End of November, I goI ...... $91 \frac{1}{8}$

End of January, I902 . . . . . 937

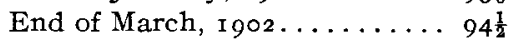

End of June, $1902 \ldots \ldots \ldots .96$

In the first place it will be seen that the decline in consols had been going on for some time before the war was thought of. The 
first date taken for comparison is July, I896, which was the culmination of a long period of shaken confidence due to the Baring collapse in 1890 . For several years conservative investors had refused to put funds into any but the most absolutely secure stocks, with the result that the prices of such stocks were unnaturally inflated. Therefore the high price of consols in 1896 was due to exceptional causes and it is only natural that as confidence in other investments was gradually restored, the price of consols should fall to a more normal level. This reaction was helped by the great business activity of 1898 and I 899 which offered large opportunities for investment at high rates of interest, leaving less demand for securities bearing a low rate, such as consols. This will account, in part, for the accelerated decline in the first half of 1899 .

Another cause, wholly independent of the war, is the approach of the time when the interest rate of consols drops automatically from $23 / 4$ per cent to $2 \frac{1}{2}$ per cent. This takes place in 1903 , and as that date approaches consols naturally lose some of their value as profit-yielding investments. Again, in April, 1899, the sinking fund devoted to the redemption of the national debt was arbitrarily reduced by $£ 2,000,000$ which were applied to current expenses. This sum would otherwise have been expended, wholly or in part, in the purchase of consols by the government and its diversion to current expenses reduced the demand for consols by just so much.

Thus far the forces tending to lower the price of consols which have been pointed out have had no connection with the war. The war itself has exerted an influence in several ways. In the first place, the large surplus revenue of the year I899-1900, which would ordinarily have been spent by the government in the purchase of its own securities, was devoted to military expenditure, thus reducing the demand for consols and consequently their price. In a direct way the war has affected the market for consols by the additional government borrowing which it has necessitated. In

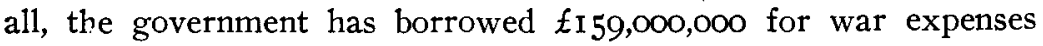
and these loans have had an important influence on the demand for capital during the past three years. Of this sum, $t 92,000,000$ have been in the form of consols and of course have had the most direct influence on their price. But the part borrowed by other means has not been without influence in decreasing the supply of available capital and so making it necessary for the government to 
give better terms. But the market does not wait for a loan to be actually made. The probable bearing of any military movement on the financial position of the government is at once discounted and its effects seen in the stock quotations. Throughout the war there has been a pretty constant tendency for the prices of consols to rise or fall according as the news from the field was favorable or unfavorable to the British arms. A reverse meant more fighting, delayed the close of the war, and made probable more government borrowing to pay the bills. A victory had the opposite effect, decreasing the probable need of the government for further borrowing.

The action of the law of supply and demand on the prices of government securities is seen in the quotations of consols at the time of the issue of the war loan in 1900 and also at the issue of the supplementary war loan in February, I90I. In both cases, as it became evident that the government would have to borrow considerable sums, and before it was known what form that borrowing would take, consols declined, but they rose quite sharply as soon as it was learned that the loan would take some other form than consols. This is shown still more plainly at the time of the issue of $£ 60,000,000$ of consols in April, I9or. As in the other two cases, consols declined steadily for some time before the loan was made, and the announcement that this time the loan was to take the form of consols caused a still further drop. At the same time other government stocks were gaining, local loans advancing a full point during April and war loan stock making a slightly smaller advance. This indicates that the fall in consols was caused by the expected increase in their amount and not by the fear that the government credit was being weakened. Finally, the eagerness with which all the government loans have been subscribed for, even by foreigners, shows that they have always been considered a thoroughly safe investment. Since the close of the war, consols have risen several points but it is not at all likely that they will again reach the high figure at which they were quoted in 1896.

\section{General Summary of Cost of War and Provisions to Meet It}

$U_{p}$ to this point the figures given have been those of the official accounts and estimates. But in order to obtain a statement of the 
total cost of the war we must add one item which the official accounts omit. This is the expense of issuing loans, including discounts. In the case of treasury bills this is accurately shown as the bills appear on the accounts at their face value while the discounts appear as interest charges on the expenditure side. In the case of all other loans, however, only the net proceeds appear on the accounts, although all were issued at a discount and their full par value must be eventually paid by the government. Therefore to the cost of the war for each year, as already given, must be added the difference between the par value and net proceeds of the loans, (other than by treasury bills), made in that year. This includes discounts in the issue price, cash discounts for anticipatory payments of installments, and miscellaneous expenses of floating the loans. The discounts on the various loans are shown below:

\begin{tabular}{|c|c|c|c|}
\hline & Par Value. & Net Proceeds. & Discount. \\
\hline $\begin{array}{l}\text { War Loan Stock (Igoo) .... } \\
\text { Exchequer Bonds (Ig0o and }\end{array}$ & $\delta_{30,000,000}$ & $\ell_{29,519,000}$ & $\ell_{481,000}$ \\
\hline rgor) $\ldots \ldots \ldots \ldots \ldots$ & $24,000,000$ & $23,423,000$ & 577,000 \\
\hline Consols (I9OI) ... & $60,000,000$ & $5^{6,553,000}$ & $3,447,000$ \\
\hline Consols (1902) . & $32,000,000$ & $29,920,000$ & $2,080,000$ \\
\hline Total & $E_{146,000,000}$ & $E_{139,415,000}$ & $\mathscr{L} 6,5^{8} 5,000$ \\
\hline
\end{tabular}

In the following table the total cost of the war for each year is made up of the three items, supply services, interest on war debt, and discounts on loans. It does not pretend to take account of any charges that may run on after the present fiscal year, such as interest on the war debt, which of course will continue till that debt is redeemed. The cost for I9O2-O3 is estimated, the figures being those of the official estimate issued in June after the close of the war, with the addition of the $£_{50}$, ooo granted to Lord Kitchener later in June. 
The Cost of the War

\begin{tabular}{|c|c|c|c|c|}
\hline YEAR. & Supply Services. & Interest. & Discounts. & Total. \\
\hline I $899-1900$. & $E_{23}, 000,000$ & $E_{217}, 000$ & & $f_{23,217,000}$ \\
\hline $1900-01 \ldots$ & $63,737,000$ & $I, 383,000$ & $f_{1,058,000}$ & 66, I7 8,000 \\
\hline $1901-02 \ldots$ & $67,670,000$ & $3,3^{6} 7,000$ & $3,447,000$ & $74,484,000$ \\
\hline $1902-03 \ldots$ & $42,250,000$ & $4,400,000$ & $2,080,000$ & $48,73 \circ, 000$ \\
\hline Four Years. & $E_{19} 6,657,000$ & $E 9,3^{6} 7,000$ & $£ 6,5^{8} 5,000$ & $E 212,609,000^{8}$ \\
\hline
\end{tabular}

The average cost per year was $£_{53}$, I $5^{2}$, 000 .

The necessary funds to pay for the war have been secured from three sources, viz: by suspending the sinking fund, by taxation, and by borrowing. The amount under each head is obtained thus: the surplus of revenue over ordinary expenditure for each year is considered as made up of two parts: (I) the suspended sinking fund, the exact amount of which is known, and (2) the tax revenue devoted to the war charge of the year; the balance of the war charge must necessarily have been met by borrowing. As we are concerned only with the South African War, the charge for the war in China is considered ordinary expenditure in this connection. The following statement shows how the war expenditure has been met:

Procisions to Meet the Cost of the War

\begin{tabular}{|c|c|c|c|c|}
\hline YEAR. & $\begin{array}{c}\text { Suspended } \\
\text { Sinking Fund. }\end{array}$ & Taxation. & Borrowing. & Total. \\
\hline $1899-1900$ & & $E_{9,334,000}$ & $\mathscr{E}_{\mathrm{I} 3}, 88_{3}, 000$ & $\delta_{23,217,000}$ \\
\hline I900-0I. . & $f_{4,547,000}$ & $7,366,000$ & $54,265,000$ & $66,178,000$ \\
\hline $1901-02$ & $4,68 \mathrm{I}, 000$ & I $3,832,000$ & $55,971,000$ & $74,484,000$ \\
\hline $1902-03$ & & $22,676,000$ & $26,054,000$ & $4^{8,730,000}$ \\
\hline Four Years & $f_{9,228,000}$ & $\mathscr{E}_{53,208,000}$ & $E_{I_{5}}$, I $73,000_{3}$ & $f_{212}, 609,000$ \\
\hline
\end{tabular}

For purposes of comparison it will be of interest to divide the provisions to cover the war expenditure into two parts by combining

"If to this be added the "extraordinary" increase in "ordinary" expenditure, about $6_{28} 8,143,000$ directly traceable to the war, a d the amount which it will cost before the govenment is again reduced to a peace footing, a conservative estimate of which is $£ 25,000,000$, the total cost of the war will be no less than $£_{2} 65,000,000$, besides increased future interest charges, pensions, etc.-[EdrTor.] 
the first two columns of the above table under the single head of taxation as follows :

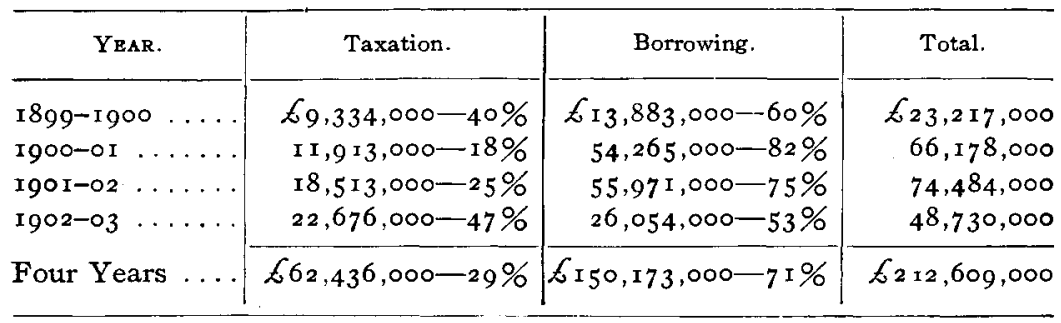

It may be of interest to compare the above figures with the corresponding figures for other wars of Great Britain. The following table ${ }^{\theta}$ shows the total cost, the parts met by taxation and borrowing respectively, and the average annual cost of all the principal wars in which England has been engaged since I688. The method used in this table to compute the war cost is slightly different from the one used in the case of the South African War, but this will nowhere make a difference of more than I per cent and so will not affect the value of a comparison.

If we consider total expenditure, the South African War is the most expensive war that England has ever waged, with the single exception of the twenty-three years' war with France (I793-I8I5), the gross cost of which was nearly four times that of the South African War. The present war, however, will have cost over twice as much as the war with the American Colonies, two and a half times as much as the Seven Years' War, more than three times the cost of the Crimean War, and from four to fifty times that of any of the other wars. Taking the duration of the wars into consideration, the South African War is by far the most costly war that Great Britain has ever been engaged in. The average annual cost of the present war is over $£ 53,000,000$. The war with France (I793I815) cost $\mathfrak{f}_{36} 6,150,000$ per year, or about 68 per cent of the annual cost of the South African War; the Crimean War cost about $\mathbb{E}_{35}$,$\infty 00, \infty 00$, or 65 per cent; the Seven Years' War and the War with the American Colonies cost each less than 20 per cent; and no other war has come up to one-tenth of the average annual cost of the South African War.

- Parliamentary Papers, 1868-69, Vol. XXXV, Part II, p. 709. 


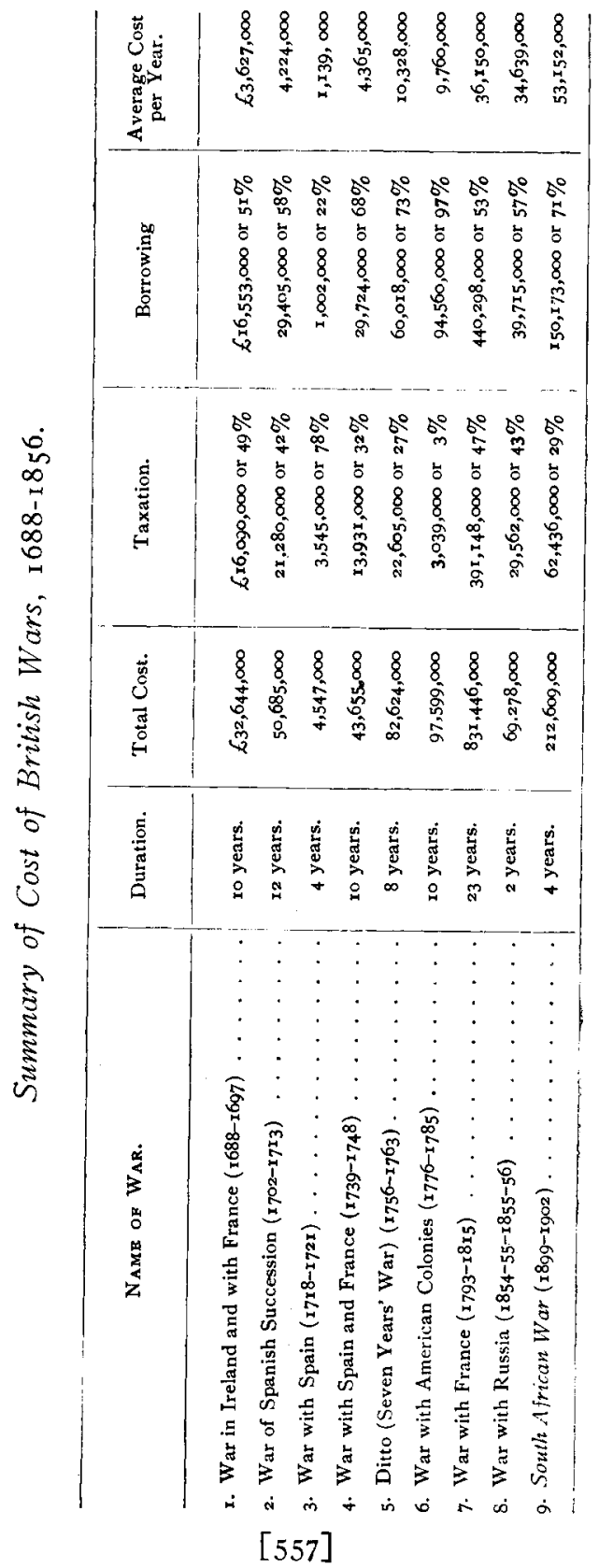

Downloaded from ann.sagepub.com at University of Manchester Library on June 3, 2015 
As regards the proportion of cost met by taxation and borrowing respectively, the comparison is not quite so striking. $U_{P}$ to I793, with the single exception of the four years' war with Spain (17I8-I72I), there is observed a growing tendency to place more of the burden of war expenditure on borrowing and less on taxation. Practically the whole of the expenditure of the war with the American Colonies was met by loans. When we come to the twenty-three years' war with France (I793-I8I5), however, we find nearly half of the cost met by taxation, and in the Crimean War 43 per cent of the expenditure was provided out of revenue. In comparison with the last two wars, the only important ones within the last one hundred years, the financing of the present war shows a rather small reliance on taxation. In fact, since 1688 only two wars, the Seven Years' War (1756-1763) and the war with the American Colonies ( $1776-1785$ ) have had so small a part of their cost met out of revenue.

F. R. FAIRChild.

New Haven, Coinn. 